髄液中リポカリン型プロスタグランジン D 合成酵素（L-PGDS）濃度は特発 性正常圧水頭症（iNPH）における狭脳梁角, 白質障害, 前頭葉機能低下と相 関する

\author{
西田 南海子 ${ }^{1)}$, 永田 奈々恵 ${ }^{3)}$, 戸田 弘紀 ${ }^{1)}$, 尾崎 彰彦 ${ }^{2)}$, 松本 禎之 ${ }^{2)}$, 石川 正恒 ${ }^{4)}$, \\ 裏出 良博3), 岩崎 孝一1) \\ 1）公益財団法人田附興風会北野病院脳神経外科，2）同 神経内科，3）大阪バイオサイエンス研究所分子行動生物学部門，4) \\ 洛和会音羽病院正常圧水頭症センター
}

\title{
Potential Role of L-PGDS as a Surrogate Marker of Narrow Callosal Angle, Age Related White Matter Change, and Frontal Lobe Dysfunc- tion in iNPH
}

\author{
Namiko Nishida, M.D. ${ }^{1)}$, Nanae Nagata, Ph.D. ${ }^{3)}$, Hiroki Toda, M.D. ${ }^{1)}$, Akihiko Ozaki, M.D. ${ }^{2}$, \\ Sadayuki Matsumoto, M.D. ${ }^{2)}$, Masatsune Ishikawa, M.D. ${ }^{4)}$, Yoshihiro Urade, Ph.D. ${ }^{3)}$, \\ and Kohichi Iwasaki, M.D. ${ }^{1)}$ \\ 1) Department of Neurosurgery, Tazuke Kofukai Foundation, Medical Research Institute, Kitano Hospital, 2) Department of Neurol- \\ ogy, Tazuke Kofukai Foundation, Medical Research Institute, Kitano Hospital, 3) Department of Molecular Behavioral Biology, \\ Osaka Bioscience Institute Foundation, 4) Department of Neurosurgery and Normal Pressure Hydrocephalus Center, Rakuwakai \\ Otowa Hospital
}

Idiopathic normal pressure hydrocephalus (iNPH) is a treatable cause of dementia, gait disturbance, and urinary incontinence in elderly with ventriculomegaly, and its unique morphological feature, called disproportionately enlarged subarachnoid-space hydrocephalus (DESH), is reported to be diagnostic. Lipocalin-type prostaglandin D synthase (L-PGDS) is a major protein in cerebrospinal fluid (CSF), produced mainly by arachnoid cells, and its concentration in CSF was reportedly decreased in iNPH. L-PGDS is a PGD2-producing enzyme, and is a lipophilic ligand carrier acting as a chaperone to prevent aggregation of neurotoxic agents, such as amyloid $\beta$ $(\mathrm{A} \beta)$. The aim of this study was to confirm the L-PGDS decrease in DESH type iNPH and to clarify its relationship with clinico-radiological features. We evaluated 22 patients (Age 75.7 $\pm 7.8, \mathrm{M} \mathrm{10} / \mathrm{F} 12$ ) referred for ventriculomegaly without CSF pathway obstruction, and conducted CSF tap test to determine the surgical indication. NPH symptoms were evaluated by idiopathic NPH grading scale, MMSE, FAB and the timed up and go test. The extent of DESH was approximated by callosal angle, and the severity of parenchymal damage was evaluated by age related white matter change (ARWMC) score. L-PGDS levels are significantly decreased in DESH patients compared to non-DESH patients $(14.4 \pm 1.0$ vs. $20.8 \pm 2.0 \mu \mathrm{g} / \mathrm{ml}, \mathrm{p}=0.01)$. Among clinical profiles, FAB negatively correlated with L-PGDS levels in whole patients (Spearman $r=-0.59, \mathrm{p}=0.005$ ) and DESH patients (Spearman $\mathrm{r}=-0.68, \mathrm{p}=0.02$ ). Moreover, L-PGDS levels positively correlated with callosal angle (Spearman $r=0.59$ ) and ARWMC (Spearman $r=0.65$ ). Our data not only support the diagnostic value of L-PGDS as a CSF biomarker of iNPH, but also propose the potential role of this protein as a surrogate marker of frontal lobe dysfunction, DESH feature and white matter damage.

(Received December 10, 2013; accepted January 14, 2014)

Key words : iNPH, L-PGDS, DESH, CSF biomarker, frontal lobe dysfunction Jpn J Neurosurg（Tokyo）23:492-497, 2014

連絡先：西田南海子, $\overline{7} 530-8480$ 大阪市北区扇町 2-4-20 公益財団法人田附興風会北野病院脳神経外科

Address reprint requests to: Namiko Nishida, M.D., Department of Neurosurgery, Tazuke Kofukai Foundation, Medical Research Institute, Kitano Hispital, 2-4-20 Ohgimachi, Kita-ku, Osaka-shi, Osaka 530-8480, Japan 


\section{はじめに}

特発性正常圧水頭症 (idiopathic normal pressure hydrocephalus：iNPH）は原因不明の成人慢性水頭症であり, 歩行障害, 排尿障害, 認知機能低下を三徵候とし, 外科 的脳脊髄液短絡（シャント）術後に症候が改善すること で診断確定に至る疾患である ${ }^{6) 13)}$. タップテスト反応性 で治療効果が予見できるのはごく一部であり7), 現在適 切に診断・治療されているのは氷山の一角とされ，高齢 化社会において診断・治療の社会的意義は大きい.一方, そのメカニズムは加齢に伴う脳のコンプライアンス低下 やくも膜機能障害に伴う脳脊髄液循環障害と仮定される ものの, 病理学的特徴にそしく, 生物学的マーカーは未 解明であり，年齢的にも症候・形態学的に似た傾向を示 すアルッハイマー病（Alzheimer's disease : $\mathrm{AD})$ 等神経 変性疾患や脳血管性認知症の合併・鑑別が困難な場合も 多く，それらが必ずしも除外基準とまではなっていな い10). しかしながら，その中に「くも膜下腔の不均衡な 拡大を伴う水頭症 (disproportionately enlarged subarachnoid-space hydrocephalus: DESH) 」) と呼ばれる均一な 画像所見を呈する一群が存在することは着目すべきであ

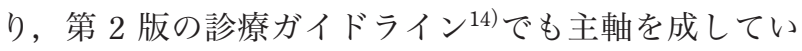
る.

iNPH の疾患概念は DESH という形態的指標によりい くぶん明確となったかにみえるが，それ以外の脳室拡大 を呈する iNPH 候補症例との違いを形態以外の面で検証 した研究はなく，その発生機序も不明である。そこで本 研究では, タップテストにて評価する三徵候の評価項目 や患者背景の違い等をDESH 所見の有無で検証するこ ととした。ささらに, 得られた髄液を用いて生物学的マー カーを検討することとし，すでに特発性正常圧水頭症全 般にて低值が報告されている L-PGDS（lipocalin-type prostaglandin D synthase, 別名 beta-trace $)^{111)}$ を選択し た。結果として，DESH 症例での低值を確認するととも に, 画像所見・臨床所見の興味深い相関現象を確認した ため，ここに報告する.

\section{対象と方法}

脳室拡大・三徵候を契機に受診され，ご本人および介 護者よりタップテスト同意の得られた 22 名 (年齢 $75.7 \pm 7.8$ 歳 男性 $10 /$ 女性 12 名）を対象とした。症状 の評価には, iNPH Grading Scale (iNPHGS) ${ }^{9)}$, Mini-Mental State Examination (MMSE) ${ }^{3)}$, Frontal Assessment Battery $(\mathrm{FAB})^{2)}$, Timed Up \& Go Test（TUG $)^{16)}$ を用いた.
タップテストは通常の腰椎穿刺の手技で行い, $30 \mathrm{ml}$ あ るいは圧が $0 \mathrm{~cm}$ 水柱となるまで排除した。得られた髄 液の一般所見に異常のないことを確認し，後半部分で得 られた余剩髄液を一 80 度で凍結保存した。髄液中 $\mathrm{L}-$ PGDS の測定は ELISA 法を用いた ${ }^{12)}$ 。分注した髄液 10 $\mu l$ を 3,000 10,000 倍に希釈し，1 次抗体として MAb$7 \mathrm{~F} 5,2$ 次抗体として horseradish peroxidase-conjugated MAb-1B7 を用いた。タップテストの施行前には，MRI $\mathrm{T} 2$ の軸位断に加えて冠状断・矢状断および CINE 画像 を施行した。軸位断で脳室拡大の指標として Evans index （\%）を測定，矢状断および CINE 画像を参考にして明ら かな閉塞機転を除外した。さらに，冠状断で $\mathrm{DESH}^{4)} の$ 所見の有無を判定，その定量的指標として後交連中脳水 道入口部を含む冠状断を参照し，脳梁角5)測定した。 問診・既往歴に明らかな脳卒中の病歴を確認できるもの は除外したうえで，全般的な白質障害の程度を agerelated white matter changes (ARWMC) 指数 ${ }^{19)}$ とて数 值化した。かかりつけ医によりすでに投与開始されてい るコリンエステラーゼ阻害薬が存在する場合は，AD を 合併しているとして取り扱い，投薬は続行した。統計学 的評価には GraphPad Prism 5.01 (GraphPad Software, Inc., La Jolla, USA) を用い, $\mathrm{p}<0.05$ を有意水準とした. 本 研究は公益財団法人田附興風会北野病院倫理委員会（承 認番号 E11-05-006，平成 23 年 5 月 17 日）により承認 された。

\section{結 果}

Fig. 1 に典型例として示すように, DESH と nonDESH は脳室拡大を認めるものの，〈も膜下腔の髄液分 布に差異がある。まず， 22 症例を DESH 所見の有無で 2 群に分けた結果を Table 1 に提示した。年齢・性別に 明らかな違いはなかったが，コリンエステラーゼ阻害薬 を内服されている $\mathrm{AD}$ 合併の可能性のある症例が DESH では 3 名, non-DESH では 5 名含まれていた。 DESH 群では 80\%がタップテスト陽性であったのに対 し, non-DESH 群では $41.7 \%$ と陽性率は低かった。それ を反映して，シャント手術に至った例は，DESH では 70\%，non-DESH では 25\%となった。 Evans index で表 される脳室拡大の程度は両群で差がなかったが, 脳梁角 は DESH 群で 79.9 度と, non-DESH 群の 101.2 度より 有意に狭小であった，ARWMC で表される白質障害の程 度はDESH で軽症の傾向であるが有意ではなく, MMSE，FAB，iNPHGS 等の臨床的尺度も DESH で軽症 の傾向を認めたが，有意ではなかった。TUGで評価した 


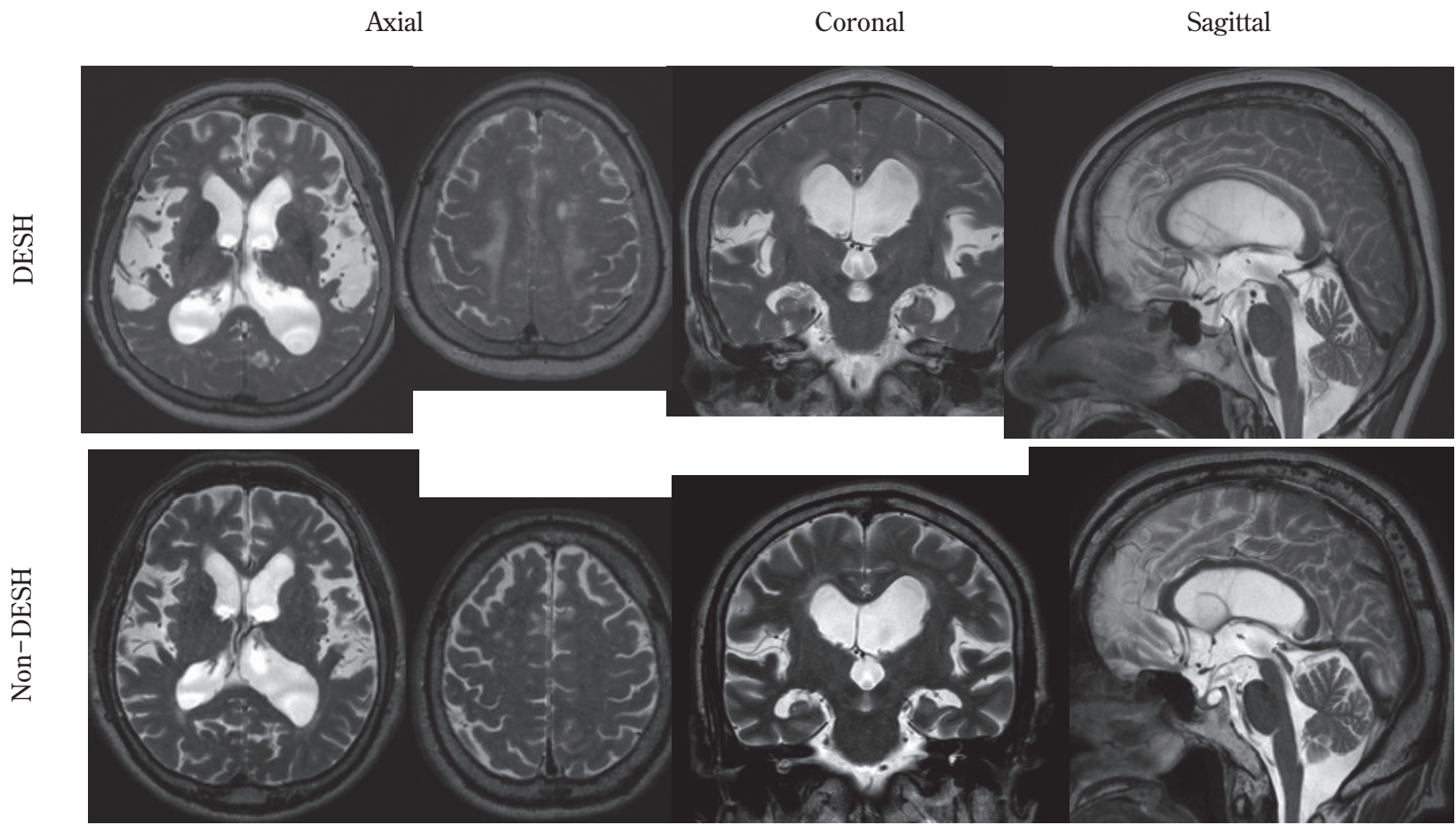

Fig. 1 Representative MR image of DESH and non-DESH ventriculomegaly

Table 1 Demographics of DESH and nonDESH patients

\begin{tabular}{lllc}
\hline & DESH & non-DESH & $\mathrm{p}<0.05$ \\
\hline Gender $(\mathrm{m} / \mathrm{f})$ & $4 / 6$ & $6 / 6$ & \\
Age & $75.7 \pm 4.4$ & $77 \pm 9.3$ & \\
Tap positive \% & 80 & 41.7 & \\
Shunt op \% & 70 & 25 & \\
Evans index & $34.5 \pm 2.8$ & $32.7 \pm 4.3$ & \\
Callosal angle & $79.9 \pm 5.5$ & $101.2 \pm 4.3$ & $*$ \\
ARWMC & $9.2 \pm 1.6$ & $13.3 \pm 2.0$ & \\
Possible comorbidity & $\mathrm{AD}(3)$ & $\mathrm{AD}(5)$ & \\
MMSE & $22.5 \pm 4.6$ & $18.1 \pm 6.4$ & \\
FAB & $11.4 \pm 4.0$ & $9.9 \pm 4.0$ & \\
TUG (sec) & $17.8 \pm 0.8$ & $29.8 \pm 5.7$ & $*$ \\
TUG (step) & $24.2 \pm 0.6$ & $38 \pm 5.0$ & $*$ \\
iNPHGS & $7.3 \pm 0.9$ & $9.1 \pm 1.0$ & \\
L-PGDS $(\mu \mathrm{g} / \mathrm{ml})$ & $14.4 \pm 1.0$ & $20.8 \pm 2.0$ & $*$ \\
\hline & & Values are mean \pm SD
\end{tabular}

歩行障害は, non-DESH で有意に重症となっていた. TUG が困難なレベルの歩行障害症例が non-DESH で 12 例中 4 例あり, 10 例対 8 例での解析となった。また, 髄液中の L-PGDS 濃度は DESH で $14.4 \mu \mathrm{g} / \mathrm{ml}$ となり, non-DESH の $20.8 \mu \mathrm{g} / \mathrm{m} l$ より有意に低值であった.

そこで, DESH と non-DESH で有意差を呈した脳梁 角, 髄液中 L-PGDS 濃度, TUG の秒数 - 歩数の診断学 的意義を評価するため, receiver operating characteristic
（ROC）解析を行った。結果として Fig. 2 に示されるよ うに，おのおの 89.6 度， $15.4 \mu \mathrm{g} / \mathrm{ml}, 20.7$ 秒， 25.0 歩を カットオフとして尤度比 $4.8,4.8,3.6,6.4$ となった。

さらに, DESH の生物学的マーカーとしての L-PGDS の意味を検証すべく, 患者背景, 臨床症状, 画像所見と の相関を検討した。結果，患者背景では年齢と有意な正 の相関 (Spearman $r=0.60)$, 症状では $\mathrm{FAB}$ と有意な負の

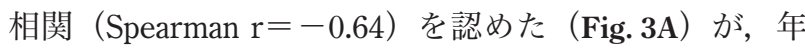
歯と FAB 自体の相関は有意ではなかった。 DESH 症例 に限定しても，L-PGDS と FAB の相関は有意であった (Spearman $r=-0.68)$ 。また，画像所見では脳梁角およ び白質障害（ARWMC）とそれぞれ有意な正の相関（お のおの Spearman $\mathrm{r}=0.59$ および 0.65)を認めた (Fig. 3B) が，脳梁角と ARWMC の直接的な有意な相関は認めな かった.

\section{考 察}

$\mathrm{iNPH}$ の疾患概念そのものに，その他の認知症をきた す神経疾患とは若干異なり，「シャント手術が奏効した」 段階で診断確定するという特異性があることは，周知の 事実ながらこの疾患の理解を難しくしている。手術に至 る前の検査はすべて補助診断にしかならないという中 で，全例が手術適応となるわけでもなく，本研究で検討 
Callosal angle

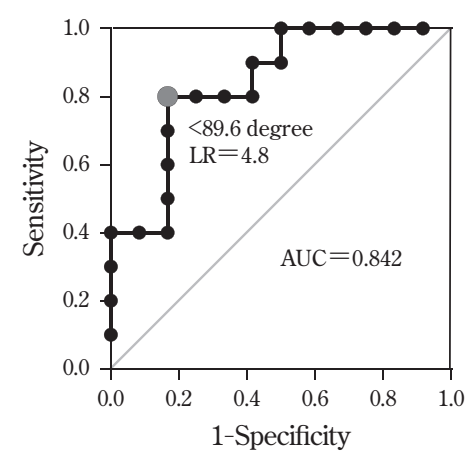

TUG (sec)

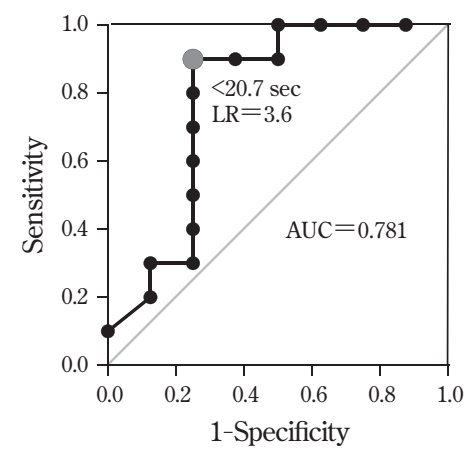

L-PGDS
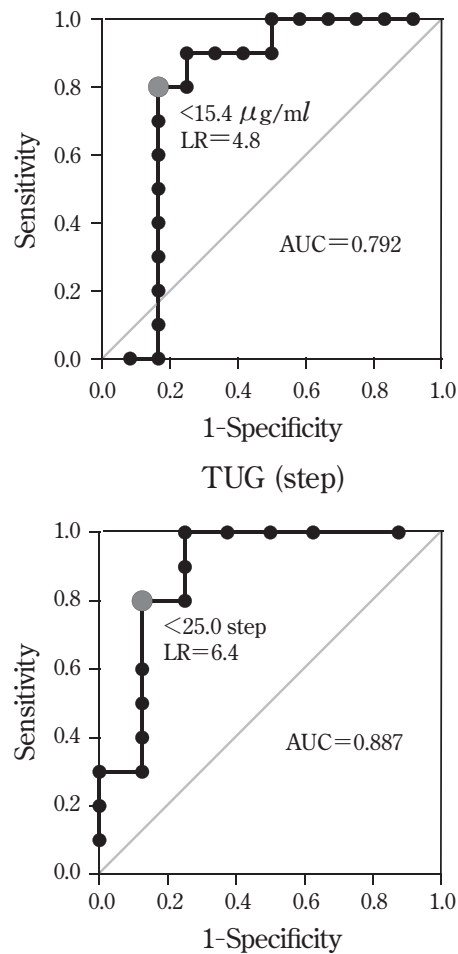

Fig. 2 Receiver operating characteristic (ROC) curves of clinical (TUG), radiological (callosal angle) and CSF (L-PGDS) biomarkers to distinguish DESH and non-DESH ventriculomegaly

A

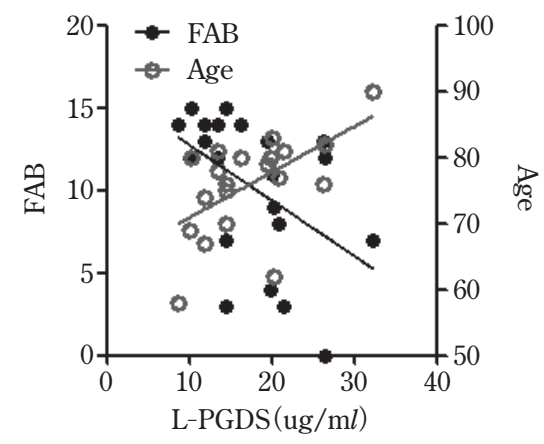

B

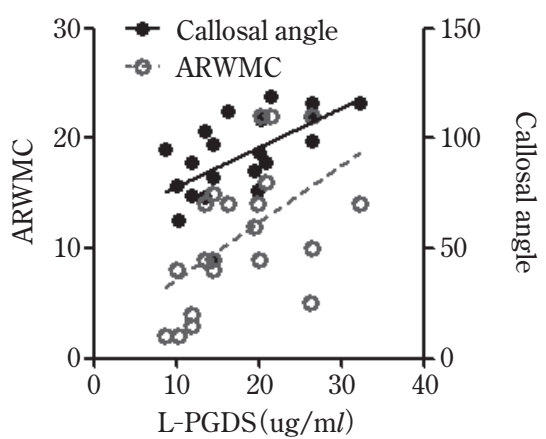

Fig. 3 L-PGDS and clinico-radiological features A : Correlation with FAB and age.

B : Correlation with callosal angle and ARWMC.

した 22 症例がそもそもすべて iNPH として一括してよ いものか，白質障害やコリンエステラーゼ阻害薬の内服 等を考慮すれば，脳血管性認知症（vascular dementia： $\mathrm{VaD} ） や \mathrm{AD}$ の合併を考えないわけにはいかない状況が あることは，本研究の明白な limitation である。しかし ながら, 臨床の現場で高齢者の頭部画像で脳室拡大を認
め, 彼らが三徴候を呈する場合は多々あるのが現実であ り, 例えば $\mathrm{VaD}$ と $\mathrm{AD}$ がしばしば明快に線引きできない のと同様に ${ }^{15)}$, それらと iNPH を線引きするのが難しく, しばしば合併があっても治療効果が部分的に見出される 症例も存在することが現実の問題として認識されつつあ る ${ }^{10)}$. その中で, $\mathrm{DESH}^{4)}$ という形態学的指標が提案され 
たことは画期的であり，そのシャント反応性の確実性が iNPH をより把握しやすい疾患概念としたが，それに対 応した髄液マーカーの検討は今までなかった。 今回, LPGDS が DESH で低值を示し, DESH の指標の一つであ る脳梁角と同等の診断学的精度を示し, 脳梁角と相関し たことは, DESH の集団の均一性を示唆するとともに, 今後, 新たな角度からこの物質を追究する意義を示すと 考えられる。

L-PGDS の低值については, 当初くも膜下出血後水頭 症を主体とした NPH 全般での低值 ${ }^{11)}$, 次いでタップテ

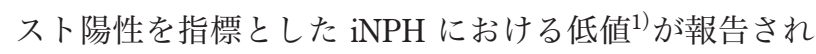
ており, 前者は本研究と同じサンドウィッチ ELISA 法, 後者は免疫比濁法を用いているが, おのおの, 正常コン トロール平均 $15.3 \mu \mathrm{g} / \mathrm{m} l$ および $25.3 \mu \mathrm{g} / \mathrm{ml}, \mathrm{NPH}$ 以外 の認知症平均 $19.1 \mu \mathrm{g} / \mathrm{ml}$ および 20.1 $24.2 \mu \mathrm{g} / \mathrm{ml}, \mathrm{NPH}$ 平均 $8.99 \mu \mathrm{g} / \mathrm{ml}$ および $17.5 \mu \mathrm{g} / \mathrm{ml}$ となっている. 特に, くも膜下出血後 NPH で著しく低值であり, 低下の背景 となるメカニズムとしては, くも膜細胞 (主たる産生源) の障害が示唆されている. 本研究ではDESH の所見を基 準に脳室拡大症例を区分しているため, DESH で 14.4 $\mu \mathrm{g} / \mathrm{ml}$, non-DESH で $20.8 \mu \mathrm{g} / \mathrm{ml}$ となっており, その カットオフ值は $15.4 \mu \mathrm{g} / \mathrm{ml}$ となったが, これは正常コン トロールの検討がないこと, また non-DESH は均一な集 団と言い難いこと, 症例数が 22 例と少ないこと等の limitation を認識して, 今後も検討追加すべき内容であろ う。しかしながら, 数值としてはある程度過去の報告に 矛盾しない範囲に収まっており, 本物質の計測の再現性 には問題がないと考えられる.

L-PGDS が特異である点は, 近年 $\mathrm{AD}$ がアミロイド $\beta$ や夕ウといった生物学的マーカーで語られるようになっ たことを背景に，これらの物質が $\mathrm{iNPH} に \mathrm{AD}$ を合併し たシャント効果の得にくい症例を除外する意味合いで用 いられるのとは異なり ${ }^{17)}$, 例えばくも膜細胞障害を示唆 するマーカーであるなどとして, さらに積極的に疾患発 症のメカニズムに関与する可能性をうかがわせる部分で ある、そればかりでなく, 年歯, 前頭葉機能, 白質障害 との線形の相関を認めたことは, iNPH と VaD との移行 に関わる物質である可能性も考慮させる。けだし $\mathrm{L}^{-}$ PGDS 低值が iNPH におけるくも膜障害を反映するので あれば，それと相関するDESHもまた，〈も膜障害を反 映した形態変化であるという仮説は成り立つ。しかしな がら,くも膜障害が強いほど L-PGDS 低值に傾くという 理論は，L-PGDS 低值であるほど, 前頭葉機能が維持さ れているという本研究結果と矛盾しているようにも思わ れる。これら一見して相容れない現象は, いまだ解明さ
れない別のメカニズムの可能性を考慮させる.

では，L-PGDS とはそもそもどのような物質であるの か、それは髄液中に最も豊富にある夕ンパク質であり, くも膜細胞および乏突起膠細胞で産生されることが知ら れ，くも膜細胞内で睡眠誘発物質であるプロスタグラン ジン $(\mathrm{PG}) \mathrm{D}_{2}$ を合成, 細胞外に輸送するとされている ${ }^{18)}$. しかし，その機能は単なる合成酵素にとどまらず，疎水 性低分子輸送に関与するリポカリンファミリーに属する という点で, レチノイドやビリベルジン等のさまざまな 疎水性低分子と結合するという, 際立って広いリガンド 選択性を有し，疎水性低分子の輸送タンパク質およびス カベンジャーとしての役割も担っている。 その具体例と して, $\mathrm{AD}$ の発症に関わるアミロイド $\beta$ ペプチドとも強 く結合し，その凝集を阻害するシャペロン機能が報告さ れており ${ }^{8)}$ ，その役割は中枢神経系の恒常性維持に広範 に関わっていると予想されている.

\section{結 語}

$\mathrm{iNPH}$ の疾患概念の中で特異的とされる DESH の所見 をサポートする生物学的マーカーとしての L-PGDS の 可能性を見出した．DESH という概念の基盤を補強する 所見であるとともに，それ自体がすでに報告されている アミロイド $\beta$ 等の有害物質の凝集防止機構など, 髄液中 に存在する中枢神経系の恒常性維持に関わる分子である ことが意義深いと考えられた。あくまでも少ない対象を もとにした結果であるが，慎重に症例を積み重ね，長期 予後との関連を見出すとともに, DESH や白質障害の MRI 評価をより定量的にする, アミロイド $\beta$ やタウなど の既知の認知症疾患の生物学的マーカーとの関連を追加 検討していく等，より客観的な評価を継続することに よって, 本疾患の輪郭を明確にする必要があると考えら れた。

\section{謝 辞}

本研究は, 日本学術振興会の科学研究費補助金（若手研究 B23791619）の助成を受けたものである.

\section{文 献}

1) Brettschneider J, Riepe MW, Petereit HF, Ludolph AC, Tumani $\mathrm{H}$ : Meningeal derived cerebrospinal fluid proteins in different forms of dementia: is a meningopathy involved in normal pressure hydrocephalus? J Neurol Neurosurg Psychiatry 75: 1614-1616, 2004.

2) Dubois B, Slachevsky A, Litvan I, Pillon B: The FAB : a Frontal Assessment Battery at bedside. Neurology 55 : 1621-1626, 2000. 
3) Folstein MF, Folstein SE, McHugh PR: "Mini-mental state”. A practical method for grading the cognitive state of patients for the clinician. J Psychiatr Res 12:189-198, 1975.

4) Hashimoto M, Ishikawa M, Mori E, Kuwana N: Diagnosis of idiopathic normal pressure hydrocephalus is supported by MRI-based scheme: a prospective cohort study. Cerebrospinal Fluid Res $\quad$ 7: 18, 2010.

5) Ishii K, Kanda T, Harada A, Miyamoto N, Kawaguchi T, Shimada K, Ohkawa S, Uemura T, Yoshikawa T, Mori E: Clinical impact of the callosal angle in the diagnosis of idiopathic normal pressure hydrocephalus. Eur Radiol 18: 2678-2683, 2008.

6) Ishikawa M, Hashimoto M, Kuwana N, Mori E, Miyake H, Wachi A, Takeuchi T, Kazui H, Koyama H: Guidelines for management of idiopathic normal pressure hydrocephalus. Neurol Med Chir (Tokyo) 48 Suppl: S1-23, 2008.

7) Ishikawa M, Oowaki H, Matsumoto A, Suzuki T, Furuse $\mathrm{M}$, Nishida $\mathrm{N}$ : Clinical significance of cerebrospinal fluid tap test and magnetic resonance imaging/computed tomography findings of tight high convexity in patients with possible idiopathic normal pressure hydrocephalus. Neurol Med Chir (Tokyo) 50:119-123, 2010.

8) Kanekiyo T, Ban T, Aritake K, Huang ZL, Qu WM, Okazaki I, Mohri I, Murayama S, Ozono K, Taniike M, Goto Y, Urade Y: Lipocalin-type prostaglandin D synthase/betatrace is a major amyloid beta-chaperone in human cerebrospinal fluid. Proc Natl Acad Sci U S A 104:64126417, 2007.

9) Kubo Y, Kazui H, Yoshida T, Kito Y, Kimura N, Tokunaga H, Ogino A, Miyake H, Ishikawa M, Takeda M: Validation of grading scale for evaluating symptoms of idiopathic normal-pressure hydrocephalus. Dement Geriatr Cogn Disord 25:37-45, 2008.

10) Malm J, Graff-Radford NR, Ishikawa M, Kristensen B, Leinonen V, Mori E, Owler BK, Tullberg M, Williams MA, Relkin NR: Influence of comorbidities in idiopathic normal pressure hydrocephalus - research and clinical care. A report of the ISHCSF task force on comorbidities in INPH. Fluids Barriers CNS $\quad \mathbf{1 0}: 22,2013$.
11) Mase M, Yamada $K$, Shimazu N, Seiki K, Oda H, Nakau H, Inui T, Li W, Eguchi N, Urade Y : Lipocalin-type prostaglandin D synthase (beta-trace) in cerebrospinal fluid: a useful marker for the diagnosis of normal pressure hydrocephalus. Neurosci Res 47: 455-459, 2003.

12) Melegos DN, Diamandis EP, Oda H, Urade Y, Hayaishi O : Immunofluorometric assay of prostaglandin $\mathrm{D}$ synthase in human tissue extracts and fluids. Clin Chem 42:19841991, 1996.

13) Mori E, Ishikawa M, Kato T, Kazui H, Miyake H, Miyajima M, Nakajima M, Hashimoto M, Kuriyama N, Tokuda T, Ishii K, Kaijima M, Hirata Y, Saito M, Arai H: Guidelines for management of idiopathic normal pressure hydrocephalus : second edition. Neurol Med Chir (Tokyo) 52: 775-809, 2012.

14）日本正常圧水頭症学会, 特発性正常圧水頭症診療ガイド ライン作成委員会編：特発性正常圧水頭症診療ガイドラ イン 第 2 版. 東京, メデイカルレビュー社, 2011.

15）「認知症疾患治療ガイドライン」作成合同委員会（編）, 日本神経学会 (監) : 認知症疾患治療ガイドライン 2010 . 東京, 医学書院, 2010 .

16) Podsiadlo D, Richardson S: The timed "Up \& Go" : a test of basic functional mobility for frail elderly persons. $J \mathrm{Am}$ Geriatr Soc 39: 142-148, 1991.

17) Tarnaris A, Toma AK, Chapman MD, Keir G, Kitchen ND, Watkins LD: Use of cerebrospinal fluid amyloid- $\beta$ and total tau protein to predict favorable surgical outcomes in patients with idiopathic normal pressure hydrocephalus. $J$ Neurosurg 115: 145-150, 2011.

18) Urade Y, Kitahama K, Ohishi H, Kaneko T, Mizuno N, Hayaishi $\mathrm{O}$ : Dominant expression of mRNA for prostaglandin D synthase in leptomeninges, choroid plexus, and oligodendrocytes of the adult rat brain. Proc Natl Acad Sci US A 90: 9070-9074, 1993.

19) Wahlund LO, Barkhof F, Fazekas F, Bronge L, Augustin M, Sjögren M, Wallin A, Ader H, Leys D, Pantoni L, Pasquier F, Erkinjuntti T, Scheltens P: A new rating scale for agerelated white matter changes applicable to MRI and CT. Stroke 32 : 1318-1322, 2001.

髄液中リポカリン型プロスタグランジン D 合成酵素（L-PGDS）濃度は特発性正常圧水頭症 （iNPH）における狭脳梁角, 白質障害, 前頭葉機能低下と相関する

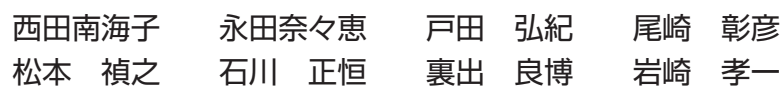

特発性正常圧水頭症（iNPH）の形態的基準である脳室拡大に付随して，DESH（disproportionately enlarged subarachnoid-space hydrocephalus）と呼ばれる髄液不均等分布が重要視されている。方, くも膜細胞で産生されるリポカリン型プロスタグランジン D 合成酵素（L-PGDS）は iNPH の生 物学的マーカーとして有力候補である. 今回, 診断目的で得る髄液中の L-PGDS 濃度を評価したとこ ろ, DESH 症例において L-PGDS が低值であること, また, L-PGDS が低值であるほど, 脳梁角が 狭く, 白質障害および前頭葉機能障害が軽度であることが示された. 


\section{Editorial Comment}

\section{iNPH の病因解明に向けて}

順天堂大学脳神経外科 宮嶋雅一

リポカイン型プロスタグランジン D 合成酵素 $\left(\mathrm{L}^{-}\right.$ PGDS）は，主にくも膜細胞において，一部はオリ ゴデンドロサイトから産生され, 血液中よりも髄液 中に豊富に存在するタンパクである。その機能は睡 眠誘発物質であるプロスタグランジン D 2 合成のみ ならず，疎水性低分子の輸送およびアミロイド $\beta$ ペ プチドなどに強く結合し，その凝集を阻害するシャ ペロン機能を有する.

本論文では髄液中 L-PGDS 濃度はiNPH の
DESH 型で低値を示し, L-PGDS 濃度と脳梁角, さ らには前頭葉機能低下との相関を示している。 LPGDS は産生部位からみて, 髄液の産生・吸収に関 与している可能性が示唆され, iNPH 診断の髄液バ イオマーカーのみならず, 病因解明にも寄与するこ とが予想される. 今後, 多施設でのバイオマーカー としての検証と, 病因解明に関連した基礎研究が期 待される。 